\title{
Muslim and Non-Muslim Perception Of Social Interaction Between Religious in Malaysia
}

\author{
*Hadana ${ }^{1}$ and Khoo Chen $\mathrm{You}^{2}$ \\ ${ }^{1)}$ Graduate Student of Geography Education, Universitas Negeri Padang, Indonesia \\ e-mail: hadanalubis1004@gmail.com \\ 2) Student of Geography, Malaya University, Malaysia \\ e-mail: chienyoukhoo@gmail.com
}

*Corresponding Author, Received: September 14, 2018, Revised: October 21, 2018, Accepted: December 05, 2018

This is an open acces article distributed under the Creative Commons 4.0 Attribution License, wich permits unrestricted use, Distribution, and reproduction in any medium provided the original work is properly cited @2017 by author and Universitas Negeri Padang

\begin{abstract}
The purpose of this study was to analyze the perception of Muslim and non-Muslim communities on the relationship between interreligious social interaction in Malaysia. Plurality or diversity is inevitable, one of which is religious diversity. Malaysia is a country with a high level of religious diversity, although most of its territory is dominated by Islam. This diversity is a challenge, especially for the government to unite it especially in that there are various differences that can cause conflict. Good interaction between religions is one way to reduce inequality or differences between religions, where with good interaction can eliminate misunderstandings that might occur. So, there needs to be research related to this. This type of research is a qualitative descriptive study, with cool research namely Muslim and non-Muslim communities in Malaysia where the sampling technique used is purposive sampling. The type of data used in this study is primary data with data retrieval techniques namely observation, interviews and documentation. Based on the results of the study showed that the perception of Muslim and non-Muslim societies on the relationship of social interaction between religions in Malaysia is very good, where both Muslim and non-Muslim communities say that they can live side by side, even though in a state life non-Muslim people still accept different treatment by the Malaysian government.
\end{abstract}

Keywords: Perception, Muslim, Non-Muslim, Interaction, Religion, Malaysia

\section{Introduction}

Increasing the number of population and the use of natural resources have resulted in new problems (Umar et al, 2017), one of the problems that arise is the emergence of plurality. Plurality is an undeniable thing that has spread and concerns various aspects of life such as ethnicity, language, customs and religion. Especially in the global era where geographic and cultural boundaries become vague, making human life into a community that guides full awareness of plurality, especially plurality of religions. This plurality is a blessing but it is also a challenge for religious people because in its plurality the bias is loaded with interests which can ultimately lead to conflict (Joergenmeyer, 1998; Hermon et al., 2018). Although in general every religion in the world surely brings a mission of peace and harmony in human life, not only with fellow religions but harmony between religious communities. Islam is one of the religions that promote interaction between people, both fellow Muslim communities and non-Muslim communities.

In Malaysia since the 15 th century, Islam was a religion that dominated the Malay tribe which later became a symbol and religious and cultural identity for the Malays. At the time of Malaysian independence, Islam had become one of the main factors in the formation of Institutions (Means, 1978; Talib et al., 2014). During independence in 1957 Islam and Malay, tribes were given special status in the Federal Constitution 
(Master, Jin and Cooper, 2000; Talib et al., 2014). Although dominated by Muslim Malays, Malaysia is one of the countries in Southeast Asia that is famous for its plural society (Talib and Gill, 2012), which is a multicultural, multi-lingual and multi-religious country, this is realized by the existence of different associations or communities living side by side and at the same time each community tries to maintain its true identity (Abdullah and Pedersen, 2003). Nevertheless, it still seems that the relationship between ethnicity and religion that still seems fragile, even though the Malaysian state has been independent for more than 50 years (Syarif, 2012).

In Malaysia, religious freedom has been regulated in the Malaysian Institution namely First in Article 1 stipulates that every person has the right to declare and explain his religion and (subject to applicable laws restricting the spread of other religions for Muslims) to spread it. Second, Institutionalization also stipulates that Islam is a religion of fellowship (not official religion), but other religions may be practised in peace and harmony (Malaysia Institution Law). Malaysia, under the auspices of the Malaysian kingdom and the law, stipulates that the state guarantees the freedom of every citizen to embrace their religion and to practice religion according to their religion.

One of the things that can be done to be able to continue to maintain differences in the need for good interaction between religions. Interaction is the key to all problems of a social life because without interaction there will not be a safe and shared life. Interaction is something that cannot be avoided, and will surely happen to every human being. Interaction involves various aspects of human harmonies, such as ethnicity, customs and religion. One function in religion is to foster brotherhood of mankind. Harmony in reality only happens to fellow religious cultivators, while the gap occurs mostly in different religious groups. This certainly can cause disputes because of the differences that exist, in addition to the factors of ethnicity, race, culture also plays a role in the gap (Hendropuspito, 1983; Suasti et al, 2018), this can also cause conflict. In Malaysia, issues related to the religious conflict cannot be known with certainty because there is no precise data related to this matter. However, some Malaysians stated that the biggest conflict that occurred after independence was the May 13 incident that occurred in 1969, although it did not occur because of religious problems but rather social problems, but this incident claimed the lives of ethnic Chinese who were mostly Buddhists and is one of the biggest humanitarian events in Malaysia. Apart from these events, Malaysia is a country that can harmonize the differences that exist in the lives of its people.

Perception is a complex mechanism that shapes a person's mindset which is the result of interaction with the surrounding environment based on the past and present and the future. Through a perception can express and solve a problem that arises. Based on the views of the sociology of religion in Malaysia, shows that the relationship between interfaith interactions is often overshadowed by the tendency towards negative perceptions that arise or exist among multi-ethnic and religious communities such as Malaysia. Malaysia is one country that has a very complex society with cultural diversity. However, there is a very clear line of difference between communities and cultures in Malaysia, which summarizes aspects of Bumiputera and Non-Bumiputera, Muslim and Non-Muslim or Malay and not Malay.

According to one of its citizens, this happened because the kingdom of Malaysia participated in responding to this difference, where religions other than Islam can live and develop in accordance with their religion as long as they are in accordance with the provisions or restrictions made by the Malaysian kingdom. Then what about the interactions that arise or are intertwined between religious communities in Malaysia, it has been running well or not. Based on the above, the researcher is interested in seeing and analyzing the perceptions of Muslim and non-Muslim communities regarding the interactions they make between religions in Malaysia. The purpose of this study is to analyze and describe the perceptions of Muslims and nonMuslims on the interaction between religions in Malaysia.

\section{Method}

The type of research used in this research is descriptive qualitative which describes the perceptions of Muslims and non-Muslims on the interaction between religions in Malaysia. The research subjects were Muslim and non-Muslim communities who were selected by using purposive sampling technique. Data collection methods used are methods of observation, interviews and documentation. The observation method used was passive participation observation (Hermon et al., 2008), to see the interaction between religions in 
Malaysia, while the interview method used was guided free interview namely in-depth interview but guided by the main questions to get the expected information. Research instruments in the form of observation width and interview guidelines. The data that has been collected is then analyzed according to the research objectives.

\section{Results and Discussion}

Humans are social beings (Hermon, 2010a), where humans depend and need other individuals or other creatures (Hermon, 2012), in living in a society (Hermon, 2015a), humans are required to interact with others well in order to create a peaceful and peaceful society. Interaction is an individual and individual relationship, where one individual can influence another individual so that there is a reciprocal relationship (Walgito, 2003; Hermon, 2016). Interaction can also be interpreted as a reciprocal relationship between one another. This social interaction can occur with other human groups as a whole which usually does not involve the personal members (Soekanto, 2010; Hermon, 2017). In human life is never separated from interaction, one of which is social interaction. Social interaction is the core of the social process which is a reciprocal relationship between various fields of life that cover the political, economic, social, legal, educational and religious fields, while the interaction of society with religion is a process of reciprocity in which the community can maintain inter-religious peace better in the future (Soekanto \& Mustafa, 1987; Putra, 2010). Social interaction itself is the main requirement for other social activities in the social process which is a special form of social interaction. Thus, social interaction can be interpreted as the relationships between individuals and between human groups and between individuals and groups of people when two people meet, then the social interaction begins at that time, where they say to each other, shake hands, talk to each other. These activities are a form of interaction pattern (Soekanto, 2010; Hermon, 2009; Hermon, 2010b ). In interacting it is necessary to pay attention to several aspects of social relations, namely; (1) the existence of actors consisting of two or more individuals, (2) the existence of an element of time, both in the present and in the future (Hermon et al., 2017), (3) the existence of an element of distance, for example, someone can connect with other people by telephone, letters and others other things, and (4) certain elements of objects or targets (Ahmadi, 1999; Hermon et al., 2018a). However, with the development of science and technology making changes to the patterns of social interaction that exist in society, one of the changing patterns of social interaction occurs in the patterns of social interaction of religious people in the world.

Furthermore, the continuation of a process of social interaction is based on various factors, including the factors of stress, suggestion, identification and sympathy. What is meant by imitation is the process of imitating not the horns or behaviour of others, this process does not always have a positive impact because it could be that what is imitated are deviant actions. In addition, imitation can also weaken or turn off the development of one's creative power. Similarly, suggestions are almost the same as imitation. While identification and sympathy are still better because they have a roar of creativity for each party that engages in these interactions. A social interaction has at least four patterns, namely cooperation, competition, conflict and conflict and accommodation. Accommodation here is a form of interaction that occurs due to a conflict resolution process that has a dead end so that all views and attitudes are accommodated in a container for a while waiting for a new solution (Soekanto, 2010; Hermon, 2014; Hermon, 2015b).

These interactions are very important because every society is a unity of one individual with another individual who is in a good interaction relationship. In sociology studies, social processes are broadly divided into two forms, namely; associative processes and dissociative processes. The associative process is divided into three types, namely cooperation, accommodation and assimilation, while dissociative social processes are divided into three forms, namely; competition, controversy and conflict or conflict (Setiadi \& Usman, 2011; Oktorie, 2017; Oktorie, 2018). And it is necessary to remember that a social interaction will not be possible if it does not meet two conditions, namely (1) the existence of social contact, literally can be interpreted together touching, this understanding is a physical meaning, that is new contact can occur if there is a relationship bodily, but there are also people who can make contact with other parties without touching it, for example by way of talking, people can relate to others, and (2) the existence of communication, has the understanding that a person gives an interpretation of other people's behaviour (which can be tangible talk, bodily movements or attitudes), what feelings the person wants to convey, then the person concerned reacts to the feeling that the other person wants to convey, so that the attitudes and feelings of the group or 
individual can know as other groups or other individuals (Soekanto, 2010; Hermon et al., 2018b). A contact can occur without communication, for example, people speak in Padang language to people who only understand Javanese. In this case, social contact has occurred, but there is no communication because one of the communication participants cannot understand what the other wants to convey. Thus, contact without communication does not mean anything in a social interaction (Maryati and Juju, 2001; Hermon et al., 2018c). So, in social interaction, there needs to be social and communication contact so that the interaction has meaning.

One of the social interactions that occur in society is social interaction between religions. In general, religion can be defined as a set of rules and regulations that govern human relations with God, regulating human relations with other humans, and regulating human relations with their environment. These rules are full of Mali's systems because basically the rules are composed of ethos and outlook on life so that the rules that exist in religion emphasize normatively or should and should be done instead of contains instructions that are practical and technical in terms of humans facing their environment or their neighbours. Religious social interaction occurs in three forms, namely; intramural, intercommunal and extra-communal. Intercommunal is an interaction that occurs in certain communities such as within the Muslim community or the Christian community and does not mix in other communities so that it often causes exclusivism, is closed and keeps a distance from other communities. While intercommunal is an interaction that occurs between communities both in the name of ethnicity and religion, such as between Muslims and Christians or Hindus with Buddhists. Meanwhile, extracomunal interaction is above the two interaction patterns. These socioreligious interactions are dynamic relationships involving the relationship between individuals, groups, and individuals with groups. There are several types of social interactions, namely (1) interaction between individuals and individuals, one of the mechanisms of which is influenced by thoughts and feelings that result in the emergence of several phenomena such as social distance, feelings of sympathy and antipathy, identity and frequency in which one individual influences, stimulates to other individuals, (2) interaction between individuals and groups, two or more people who have the purpose of leasing to interact with each other and dependence on achieving common goals, for example between agricultural extension workers and farmers.

The relationship between social interactions between religions is one very important factor in building harmony and harmony in a country, especially in countries that have a population with a high level of religious diversity, such as Malaysia. Malaysia is a multi-religious society and Islam is its official religion. According to the 2000 Population and Housing Census, nearly 60.4 percent of the population embraced Islam; 19.2 percent of Buddhists; 9.1 percent Christian; 6.3 percent Hindu; and 2.6 percent of traditional Chinese religion. The rest are considered to embrace other religions, such as Animism, Folk Religion, Sikhs, and other beliefs; while $1.1 \%$ are reported as not religious or not providing information. All Malays are seen as Muslims (100\%) as defined in Article 160 of the Malaysian Constitution. Additional statistics from the 2000 Census which show that Malaysians mostly embrace Buddhism (75.9\%), with a significant number following Taoist teachings $(10,6 \%)$ and Christian (9.6\%). Most Indian-Malaysians follow Hinduism (84.5\%), with a small number following Christianity (7.7\%) and Muslims (3.8\%). Christianity is the dominant religion for Bumiputra non-Malay community (50.1\%) with an additional 36.3\% known as Muslims and 7.3\% officially classified as followers of popular religion. In the Malaysian Constitution, all people are seen as fully Muslim. In addition, in the 2000s statistics showed that Malaysians mostly embraced Buddhism with a significant number who followed Taoist teachings and also embraced Christianity as much as $9 \%$. Whereas the majority of Indian-Malaysians embrace Hinduism and only a small number embrace Christianity and Islam. In the legislation in Malaysia, it is theoretically guaranteed that there is religious freedom. However, in praxis, there is always a deviation that is contrary to the sound of the great constitutional text. For example, when all nonMuslims who marry Muslims, they are required to leave their original religion and then convert to Islam. In addition, non-Muslims also often get some obstacles, especially when they want to carry out their religious activities. In Malaysia, a Muslim is required to follow various decisions made by the Sharia Court when dealing with beliefs and obligations as a Muslim. Among them which are regulated in the decision are marriage, inheritance, apostasy and also internal relations among fellow Muslims. There is no criminal or civil violation in this Sharia Court, but the Civil Court which is actually the highest court in Malaysia is reluctant to lead cases involving Islamic law within the territory that is the Sharia Court's authority. 
In Malaysia, there is not much literature related to issues that discuss social relations between Muslim and non-Muslim communities in Malaysia, this is probably because most of the issues related to this are very sensitive to some parties, causing many researchers who are reluctant to bring this issue into writing. The application of the principles of appropriate interaction with non-Muslim groups is one of the important elements that play a role in creating harmonization of the relationships of social interaction created between the two groups. Basically, there are several studies that have been carried out in relation to the principles and principles that need to be understood to ensure the realization of interactions that are not out of the rules of each religion. In addition, equality and justice that should be needed to be given to each community without knowing the existence of religious differences in order to eliminate elements of inter-religious conflict and conflict, and also the government does not have to continue to interfere with religion because every individual may choose the religion they believe in.

Based on the research conducted shows that there are several aspects that form the perception factors in the community related to the relationship of social interactions between religions, such as the sensitivity of each nation to religion that they believe can lead to the emergence of unreasonable, insulting speech or action that causes a feeling of not zinc, angry and others. Non-Muslim communities state that they realize that Islam and Malay are important aspects of the formation of the Malaysian state so that both need to be viewed in the same perspective by avoiding elements of prejudice and partiality. Because these things can be a barrier to the realization of harmony between religions. Therefore, both parties, Muslims and nonMuslims must tolerate each other's feelings, such as Muslim and non-Muslim societies must overcome a negative perspective on each religion, and must also realize that each of these religions lives and develops around them who also has certain rights in carrying out religion and so on as long as it does not violate what has been law or the existing narration. Islamization is also one aspect of the formation of the Malaysian state because it is considered as a reinforcement of Malay ethnic domination in the political and social system in Malaysia. Although in reality, the Muslim community is not only ethnic Malay, there are also Chinese, Indian and other communities that are in the law of Islam. This can then lead to the emergence of a sense of alienation for non-Muslims with the existing Islamization process, which can then lead to divisions within the state. So, building a country that has a tolerance between its people is not easy because there are various challenges that need to be faced.

Then the perception of non-Malay people towards the Malay community, as well as the perception of the Malay community towards non-Malays, namely: the perception of the non-Malay community towards Malay, namely; Negative attitudes towards Malay discussion, lacking in the history and background of the Malaysian state even though they have long lived and lived in the country of Malaysia, have an attitude that is more selfish than other people, has an attitude that prevents the growth of pure values on the basis of liberalization and democracy. and has an attitude of feeling that the peacock is often oppressed and a secondclass nation in Malaysia. Whereas, Malay perception towards non-Malay, namely; Still doubtful about the honesty and loyalty of non-Malays to the Malaysian state, not sympathetic to the suffering and misery experienced by non-Malays, having prejudices that are not good for non-Malays, and reluctant to accept the diversity of languages, cultures and religions that form into one asset. those who are very valuable can help in developing the Malaysian nation (Amri, 2007). This statement shows that in the community there is still a negative perception, which if not eliminated can lead to divisions which then affect the unity of the Malaysian state itself. However, this statement or perception does not fully exist or develop in the community, because based on interviews conducted with the Malays who represent Muslims and non-Malays, those who represent non-Muslims state that they have lived harmoniously without significant conflict. Furthermore, one Muslim informant said that he did not have negative thoughts or perceptions of non-Muslim communities in Malaysia, and added that he was very jealous of the work ethic that existed or developed in non-Muslim communities, especially China.

Furthermore, the results of the research on insulin and non-Muslim community perceptions of the interreligious social interaction relations in Malaysia indicate that the relationship between interfaith social interactions in Malaysia went well, although some non-Muslim sources stated that there were still differences in treatment they received from the government which according to them is still a lot of their rights that are still limited by the government, even though this is not too much about the social interaction they do with Muslims in Malaysia. Both Muslim and non-Muslim speakers who were interviewed during the research process stated that interfaith relations in Malaysia have been very conducive and every religion tries to 
respect each other, this can be seen when celebrating certain religious holidays, adherents of other religions will respect this by not disturbing or damaging the process of celebrating the religious holiday. So, in general, the perception of Muslims and non-Muslims on the relationship of social interaction between religions in Malaysia has been conducive so far, is safe both in the internal relations of religious communities, between religious and religious communities with the government and in the implementation of religious teachings in accordance with the teachings each religion.

\section{Conclusion}

Based on the results of research conducted on the perceptions of Muslims and non-Muslims on the relationship of social interaction between religions in Malaysia, it can be concluded that in general the perception of the community, both Muslim and non-Muslim societies, states that there are no major problems or large conflicts that can disrupt relations, between religious communities in Malaysia, meaning that Muslim and non-Muslim communities state that the relationship between social interactions between religions in Malaysia goes well and harmoniously. However, Malaysia as a Muslim majority country, where there is around $60 \%$ per cent of the population is Islamic, causing differences in Muslim and non-Muslim communities in Malaysia, although in the legislation guarantees the existence of diverse freedom, but in practice, non-Muslim communities still receive different treatment from the Malaysian government. However, overall the relationship between the social interaction of Muslim and non-Muslim communities in Malaysia is good, harmonious, harmonious, and every religion can live side by side in Malaysia.

\section{References}

Abdullah, A and P. Pedersen. 2003. Understanding Multicultural Malaysia: Delights, Puzzles \& Irritations. Petaling Jaya: Pearson, Prentice Hall.

Ahmadi, A. 1990. Psikologi Sosial. Jakarta: Rekana Cipta.

Hendropuspito. 1983. Sosiologi Agama. Yogyakarta : Kanisius

Hermon, D., Khairani., Daswirman., S. Karim., Dasrizal., and Triyatno. 2008. Metode dan Teknik Penelitian Geografi Tanah: Aplikasi Instrumen dan Acuan Penelitian Geografi Fisik. Yayasan Jihadul Khair Center.

Hermon, D. 2009. Dinamika Permukiman dan Arahan Kebijakan Pengembangan Permukiman pada Kawasan Rawan Longsor di Kota Padang. Disertasi. IPB Bogor.

Hermon, D. 2010a. Arahan Kebijakan Pengembangan Permukiman pada Kawasan Rawan Longsor di Kota Padang. Jurnal SKALA. Vol. 1.

Hermon, D. 2010b. Geografi Lingkungan: Perubahan Lingkungan Global. UNP Press.

Hermon, D. 2012. Mitigasi Bencana Hidrometeorlogi: Banjir, Longsor, Degradasi Lahan, Ekologi, Kekeringan, dan Puting Beliung. UNP Press. Padang.

Hermon, D. 2014. Desain Kebijakan Tanggap Darurat dan Pemulihan Bencana Letusan Gunung Sinabung. Seminar Nasional Geografi. Master Program of Geography Education, Universitas Negeri Padang.

Hermon, D. 2015a. Geografi Bencana Alam. Jakarta: PT RajaGrafindo Persada.

Hermon, D. 2015b. Arahan Kebijakan Keberlanjutan Pendidikan 10 Tahun Pasca Bencana Tsunami di Kabupaten Aceh Jaya Provinsi Aceh. Seminar Nasional Geografi. Master Program of Geography Education, Universitas Negeri Padang.

Hermon, D. 2016. Mitigasi Perubahan Iklim. Rajawali Pers (Radjagrafindo).

Hermon, D. 2017. Climate Change Mitigation. Rajawali Pers (Radjagrafindo).

Hermon, D., Iskarni, Paus., Oktorie, Olivia., and Wilis, Ratna. 2017. The Model of Land Cover Change into Settlement Area and Tin Mining and its Affecting Factors in Belitung Island, Indonesia. Journal of Environment and Earth Science. Volume 7 No. 6. p: 32-39. IISTE. 
Hermon, D., Ganefri., A. Putra and O. Oktorie. 2018a. The Model of Mangrove Land Cover Change for the Estimation of Blue Carbon Stock Change in Belitung Island-Indonesia. International Journal of Applied Environmental Sciences. Volume 13. Issue 2. p: 191-202. Research India Publication.

Hermon, D., Y. Suasti., Ernawati., Afdhal., and H. Edial. 2018b. Geografi: Geografi untuk SMU. Jurusan Geografi Universitas Negeri Padang.

Hermon, D., A. Putra., and O. Oktorie. 2018c. Suitability Evaluation of Space Utilization Based on Enviromental Sustainability at The Coastal Area of Bungus Bay in Padang City, Indonesia. International Journal of GEOMATE. Volume 14. Issue 41. p: 193-202. Geomate International Society.

Joergenmeyer, M. 1998. Menentang Negara Sekuler, Kebangkitan Global Nasionalis, terj,Nurhadi, Bandung: Mizan

Maryati, K and J. Suryawati. 2001. Sosiologi Untuk SMA dan MA Kelas X. Jakarta: Erlangga.

Oktorie, O. 2017. A Study of Landslide Areas Mitigation and Adaptation in Palupuah Subdistrict, Agam Regency, West Sumatra Province, Indonesia. Sumatra Journal of Disaster, Geography and Geography Education. Volume 1. Issue. 1. p: 43-49. Master Program of Geography Education.

Oktorie, O. 2018. Model Kebijakan Responsif Pemulihan Bencana Letusan Gunung Sinabung. Jurnal Kapita Selekta Geografi. Volume 1. Issue 1. p: 15-20

Setiadi, M. E and U. Kolip. 2013. Pengantar Sosiologi; Pemahaman Fakta dan Gejala Permasalahan Sosial. Teori Aplikasi dan Pemecahan, Jakarta: Kencana.

Soekanto, S and M. Abdullah. 1987. Sosiologi Hukum Dalam Masyarakat. Jakarta: CV Rajawali.

Soekanto, S. 2010. Sosiologi Suatu Pengantar. Jakarta: PT Raja Grafindo Persada

Suasti, Y., Barlian, E., Muchtar, B., Syah, N., \& Putra, A. .2018. Insert Religious Model in the Construction Character of Care for the Environment to the Study of Geography in Padang City-Indonesia. Journal of Islamic Studies, 6(1), 67-70.

Putra, A. 2010. Penerapan Pembelajaran Kooperatif Model Group Investigation Pada Mata Pelajaran IPS Geografi. Laporan Penelitian Tindakan Kelas.

Talib, A. T., and Gill, S. S. 2012. Socio-Religious Tolerance: Exploring the Malaysian Experience. Global Journal of Human Social Science, 12(8), 49-54.

Talib, A.T. 2014. Persepsi Terhadap Toleransi Sosio Agama di Sabah dan Sarawak. Seminar Antarabangsa Dakwah \& Etnik 2014: Da'wah \& Ethnicity: Multidisciplinary Perspective

Undang-Undang Perlembagaan Malaysia, Fasal 11: Perkara 3.

Iswandi, U. 2017. Prioritas Pengembangan Kawasan Permukiman Pada Wilayah Rawan Banjir di Kota Padang. Provinsi Sumatera Barat. Majalah Ilmiah Globe, 19 (1), 83-94.

Walgito, B. 2003. Psikologi Sosial Suatu Pengantar. Yogyakarta: CV Andi Offset. 